\title{
Every Six Days
}

National Cancer Institute

\section{Source}

National Cancer Institute. Every Six Days. NCI Thesaurus. Code C161335.

Planned or occurring every six days. 